panied by a decided deficiency of the band on the green side, called by Piazzi Smyth "the low sun band." Hence we have less red than usual and more green. = This i; due, in part at least, to the sunlight passing through a more than ordinary dense stratum of aqueous vapour, for we know that the thicker the stratum of vapour the more is the red light absorbed. But this is not all, for we have quite as much vapour without this green colour, but in these cases the sun, I believe, is not seen at all, but we get strips of green sky which are often seen. The atmosphere then, I believe, contains at present a large amount of vapour existing actually as vapour, and not condensed into clouds; hence even a great thickness of it is transparent except to those particular rays which aqueous vapour absorbs. The green colour can be seen only at a particular altitude, for only there is the thickne $s$ sufficient to produce the necessary absorption. At higher altitudes the peculiar pale silvery white is exactly what we are to expect.

WrLL you allow me to submit to the further consideration of the competent whether this phenomenon, seen at approximately the same time in Southern India, Ceylon, and the West Indies, could be due solely to the presence in the atmosphere of the vapour of water. Is not the air in these regions normally surcharged through a considerable period of every year with vapour of water? And yet not only is this an unusual appearance, but it has excited, wherever observed, both wonder and some alarm. In one respect the observation from Ceylon (NATURE, vol. xxviii. p. 597) is the most noticeable we have had yet, inasmuch as, even when the sun had attained "the very zenith," his light is said to have continued blue. My doubt is whether a phenomenon so rare could be due solely to a cause so everywhere common.

Bregner, Bournemoutb, October 22

HENRY CECIL

P.S.-When Mr. Lockyer saw his green sun through the steam on the boat, were there not also mingling with the vapour sulphurous inmes from the funnel?

[The sun has been seen green through mist on the Simplon. -ED.]

\section{Snake Poison}

Touching the effect of Crotalus venom on vegetable life, I am anxious to repair an error which appears on p. 552 of my work on "Snakes," where Dr. Mitchell is made to affirm that some healthy vegetables inoculated with the poison were "withered and dead next day, as if scathed by lightning." In some notes which I made many years ago on a too cursory reading of Dr. Mitchell's paper, ${ }^{1} \mathrm{I}$ omitted the inverted commas, which denote that the experiment was tried by Dr. Gillman of St. Louis, in I854, but which Dr. Mitchell thought was too limited and wanting in detail to be of scientific value.' I had overlooked Dr. Mitchell's comments and his own experiments on vegetable life, by which he was driven to the conclusion that the plants were injured by mechanical wounds, and not by the venom inserted into them. When writing my chapter under pressure of time long afterwards, I trusted too confidently to those careless notes, and to an impression gained through the old Virginia writers that venom is injurious to vegetable life.

But in a most interesting series of experiments twenty-five years ago Dr. Weir Mitchell found that the venom did not interfere, nor did it arrest alcoholic fermentation and its accompanying growth of sporules. To test it on the higher vegetable life he wounded plants in various parts of their stem and in various ways, taking three or four plants of similar size and growthgeraniums, tradescantia, and others-both succulent and of woody fibre, inserting venom into some and not into the others which were identical in character, and carefully noting the effects on each, which, for the most part, were similar in the inoculated and the merely wounded plants, the symptoms being such as were produced from the injury to the tissue, the leaf, or stom, as might be. "In many successive efforts to poison other plants with venom," says Dr. Mitchell in summing up the results, "I failed in every instance."

A more careful perusal of Dr. S. W. Mitchell's paper now enables me to offer this explanation of the misrepresentation of

" "On the Venom of the Rattlesnake,", by Di. S. Weir Mitchell, D.C, United States.) those exceedingly interesting experiments, fully detailed in vol. xii. of the "Smithsonian Contributions."

Cleveland, Ohio

Catherine C. Hopley

\section{Simultaneous Affections of the Barometer}

My thanks are due to Dr. Balfour' Stewart for his kindly pointing out that simultaneous movements of the barometer, like those I had described in my paper of January last, and also in the "Brief Sketch of the Meteorology of the Bombay Presi dency in I881," written in August, I882, were first observed by the late John Allan Broun. Owing to my connection with meteorological work being short-of only fourteen months' duration-my attention had not before been drawn to this fact. It is to me interesting to learn also that the late John Allan Broun considered that there was a connection between these movements and the earth's magnetism.

The Proceedings of the Manchester Literary and Philosophical Society for the last few years do not appear to have been received in Bombay, but they have now been applied for.

Meteorological Office, Bombay, September I4

$$
\text { A. N. Pearson }
$$

\section{Table of Different Velocities}

IN reading over the interesting table of velocities drawn up by Mr. James Jackson, and published in NATURE to-day (p. 604), there is one item omitted, which the author may like to add to his list, viz. the rate at which detonation travels, as exemplified by a train of compresser gun-cotton. This has been computed by $A$ bel and $N$ obel to be between 17,000 and 19,000 feet per second, or rather more than 200 miles in a minute. In $\mathrm{Mr}$ Jackson's table, therefore, the detonation of gun-cotton would come in somewhere between the velocity of sound in water and the velocity of electricity.

Woolwich, October I8

H. Baden Prítchard

\section{OSWALD HEER}

WE briefly announced last week the death, on September 27, at Lausanne, of Dr. Oswald Heer, Professor of Botany in the University of Zurich, aged seventy-four years and twenty-seven days. He was born at Nieder Uzwyl, Glarus, Switzerland, August 31, 1809. His whole mind seems to have been imbued from an early age with an intense love of nature, and his devotion to it led him to prefer its study to the discipline of the Church, which he had entered. Heer's early reputation was made as an entomologist, and from 1834 forwards he published many works and papers on entomology, chiefly on Swiss insects, and more especially on Coleoptera, most of which treated exhaustively on the vertical distribution of species in the Alps. Possibly he is best known (as an entomologist) in this country by his monographic work on the beetles of Switzerland, which appeared in 1838-4I, In this work he did for the Coleoptera of that country what Frey has more recently done for the Lepidoptera, but, of course, lapse of time has rendered Heer's labours out of date as compared with Frey's. This monograph appeared in two forms, but that which is best known was styled "Fauna Coleopterorum Helvetica," and extended to over 600 pages. But his attention was soon attracted, perhaps by some fortunate chance, towards the remains of plants which were being disinterred from the Tertiaries to the north of Lausanne and elsewhere on the Lake of Geneva, and his whole energy became absorbed in unravelling and restoring the vegetation of the past, and continued so until the close of a laborious life. In 1855 appeared the sumptuous "Tertiary Flora of Switzerland," a work which at once placed him in the first rank as a specialist; and being a prolific and imaginative writer, untiring industry, he has since contributed to palæontology a nearly uninterrupted series of works on his favourite subjects, terminating but last year with the sixth volume of the "Flora Fossilis Arctica." Few earnest workers have lived to see their work more highly appreciated, and the gratification he must have felt at the sub- 